\title{
Power Generation by Screw Type Turbine
}

\author{
Prof. Sagar P. Thombare ${ }^{1}$, Prof. Vikrant D. Nichit ${ }^{2}$, Prof. Priyanka K. Hire ${ }^{3}$ \\ Head of Department, Electrical Engineering, Matoshri Aasarabai Polytechnic, Nashik, India ${ }^{1}$ \\ Head of Department, Mechanical Engineering, Matoshri Aasarabai Polytechnic, Nashik, India ${ }^{2}$ \\ Lecturer, Electrical Department, Matoshri Aasarabai Polytechnic, Nashik, India ${ }^{3}$
}

\begin{abstract}
The intention of any hydroelectric generating station is to convert potential energy associated with the water in a watercourse passing the station into electrical energy. Landustrie has broad experience in the field of screw pumps and screw pump installations. For nearly 100 years Micro-hydro power plants has designed, manufactured, supplied, erected and maintained many types of screw pump configurations. Since the early eighties Micro-hydro power plants has had available a fully automated screw pump selection program which is used to select the optimum screw pump for a particular application. The program is based on a large number of tests, with an equal number of variables; in the Micro-hydro power plants test facility. [1]
\end{abstract}

Keywords: SCREW Type Turbine, Landustrie.

\section{INTRODUCTION}

Micro-hydro power plants have a capacity of $1 \mathrm{MW}$ or less. Micro-hydro generating systems have different environmental impact profiles than larger scale hydro generating plants. The screw turbine is typically covered in an inclined trough and is free to rotate along the axial length. When used as a pump, the lower end of the screw is placed in water and mechanically rotated. As the turbine rotates, the turbine rotates in the axial length of the screw to a higher elevation.

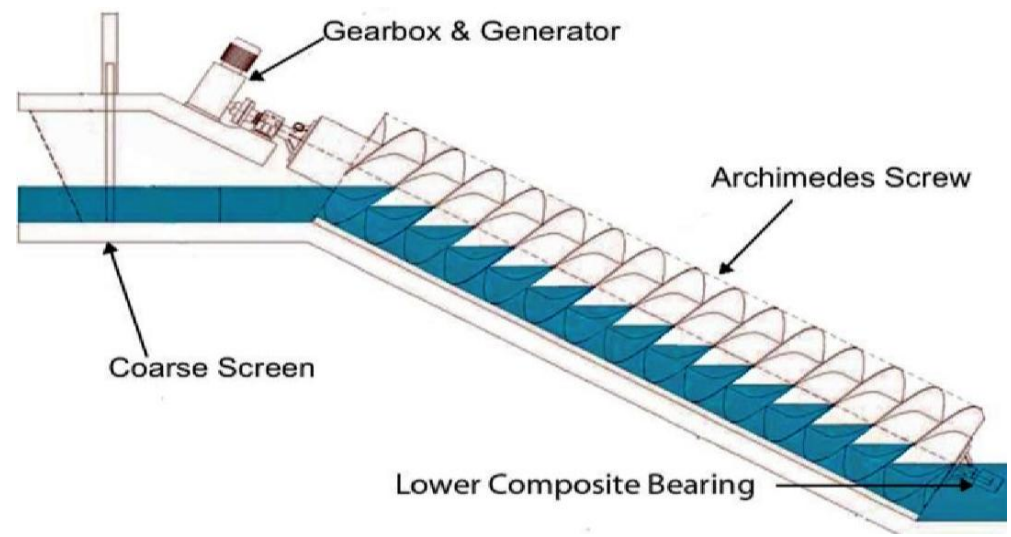

Fig. 1Archimedes screw generator system

Water is introduced to the top of the screw and allowed to flow through the screw from high to low elevation. As the water transverses the screw, the formed water buckets create a difference in pressure on the opposite sides of the helical planed surfaces. Because of the shape of the plane surfaces, a component of this pressure differential force always acts in a direction normal to the central cylindrical shaft causing the screw to rotate. Connecting a gearbox and generator to the screw shaft, the mechanical rotation can be converted to electrical power. While Screw type turbine technology dates back to antiquity, their use as generators is relatively new. [2]

\section{OPERATION}

The principle of the LANDY hydropower screw date back to 300 B.C., when Archimedes invented the screw pump .In the last decade Landustrie altered the design, making the screw pump suitable for hydropower: the LANDY hydropower screw .By placing the screw inclined in the flow direction of a river, the water stream is directed into the screw. When water enters the screw blades, the amalgamation of potential and kinetic energy of the water forces the screw to rotate. The higher the potential or kinetic energy, hence a higher head or flow, the higher the output power. The relatively slow rotational motion of the screw is transferred via a gearbox to the generator. Here the rotational 
energy is converted into electrical power, ready to use or to sell to the grid. The most straight forward projects will answer yes on both questions. [3]

A dysfunctional hydropower plant is also suitable to be placed by the LANDY hydropower screw Outlets of sewage treatment or hydropower plants Existing hydropower plant's overspill or fish by-wash.

\section{Operation Modes are:}

\section{Constant Speed}

When the available flow, the upper water level and the head, are fairly constant throughout the year, the constant speed system is the most efficient way of operation.

\section{Variable Speed}

In case the water levels and flow do vary significantly, a variable speed system could provide the best overall power generation. An extra advantage is the capability of regulating the upper water level, by regulating the speed of the screw.

\section{Variable Hybrid Drive}

Where river conditions provide enough water to run at full speed for much of the year, yet require river level regulation due to lower flows at other times, a hybrid drive may be the answer. This structure allows the turbines to run at the most efficient constant speed when possible and switch to variable speed when necessary, yielding the best possible annual energy creation. [4]

\section{Turbine Diagram}

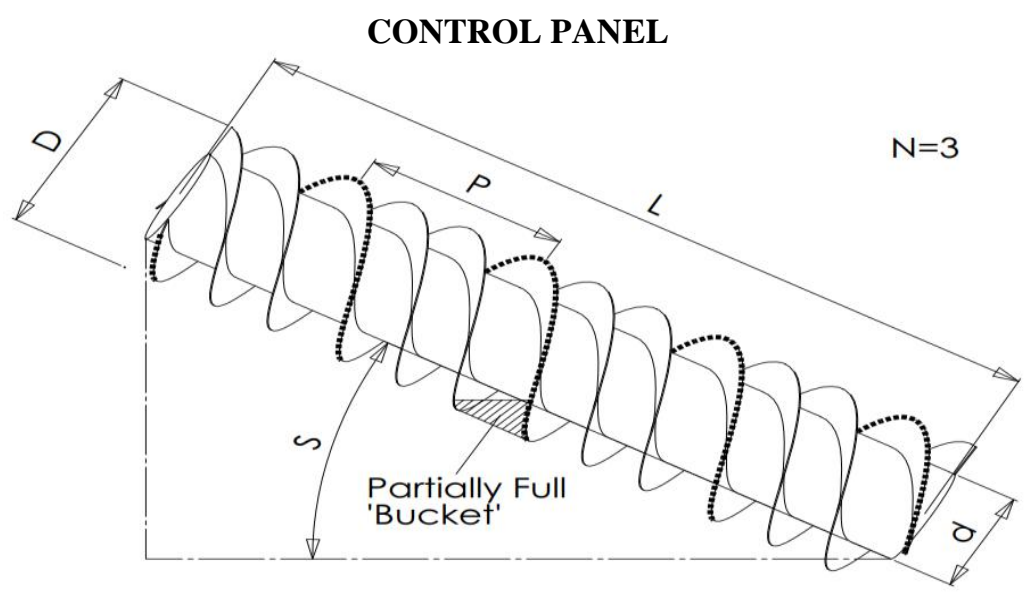

Fig. 2 Turbine dimension

\section{High Efficiency}

The LANDY hydropower screw maintains its high efficiency, even if the available flow decreases to $20 \%$ of the design flow. In cases of higher flows, or a fluctuating head, the hydropower screw performs better than any other standard turbine type and is the turbine to use in virtually any low head site.

\section{Maintenance}

Both preventive and if required, corrective maintenance for the installation, can be provided by Landustrie. Furthermore, replacement parts are easily available and can be quickly dispatched to your site for maintenance, ensuring the all important system up-time is achieved. [5]

Power calculation thumb rule:

Where,

$$
\mathbf{P}=\mathbf{Q} \times \mathbf{g} \times \mathbf{H} \times \mathbf{n}
$$

$\mathrm{P}=$ power in $\mathrm{Kw}$

$\mathrm{Q}=$ flow in $\mathrm{m}^{\wedge} 3 / \mathrm{sec}$.

$\mathrm{g}=$ gravity $9.81 \mathrm{~m} / \mathrm{sec}^{\wedge} 2$

$\mathrm{H}=$ head in meters

$\eta=$ overall efficiency app. $75 \%$ 


\section{Complete Installation}

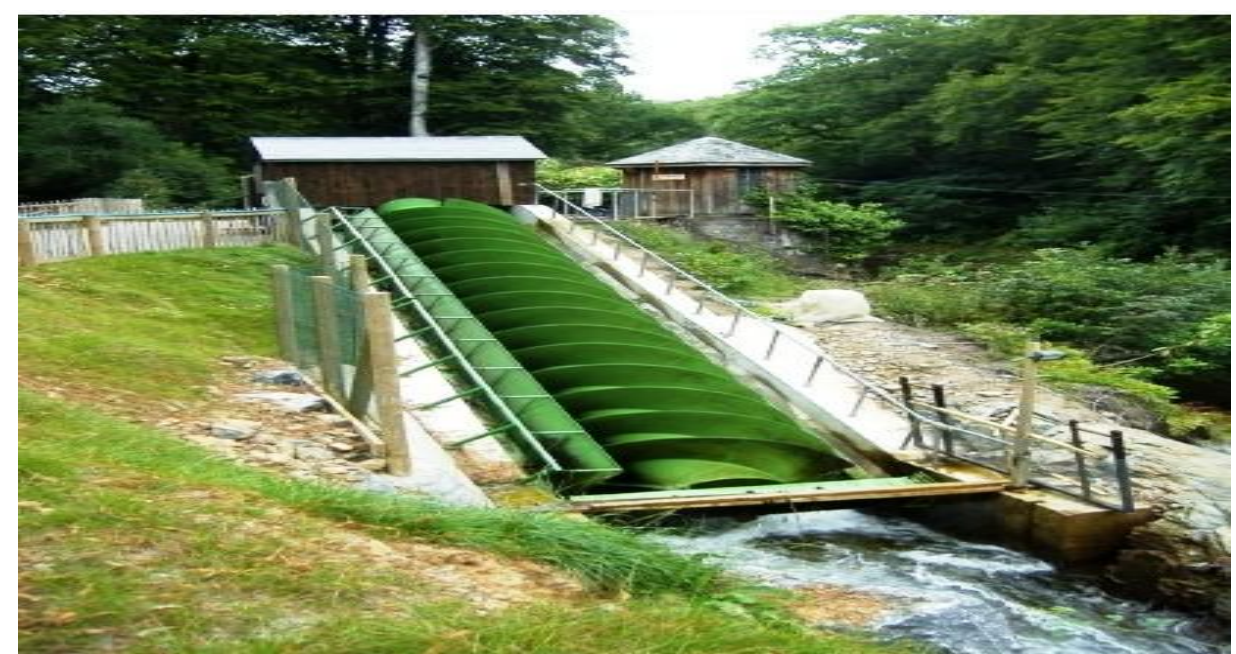

Fig.3 Installation of turbine

\section{Efficiency}

1. Independent verification of performance

2. Very accurate ultrasonic flow meter used

3. Results matched quoted specifications:

4. Screw efficiency of $87 \%$

5. Water to wire'efficiency of up to $77 \%$

6. Highly efficient down to $20 \%$ of maximum flow

7. Variable speed system offers significant benefits

\section{Archimedean Screw Operational Range}

1. Capacity from $1001 / \mathrm{s}$ to $10,0001 / \mathrm{s}$

2. Full capacity with reduced head

3. Hydraulic head from $1 \mathrm{~m}$ to $10 \mathrm{~m}$

4. No head loss from screens or pressure pipes

5. $87 \%$ hydraulic efficiency

6. 77\% 'Water to Wire' efficiency

7. Operation down to $15 \%$ max flow

8. $1 \mathrm{~kW}$ to $350 \mathrm{~kW}$

\section{Advantages}

The Archimedean hydropower screw has following advantages compared to classic turbines:

1. Highest possible efficiency under any possible condition

2. Self-regulating to changing water flow Simple and small installation

3. Easy implementation in existing situations

4. Entirely fish friendly

5. Open and robust construction

6. Ultra long life time of at least 30 years Insensitive to clogging

7. Operates completely without fine screen

8. Low maintenance costs $24 / 7$ energy supply

9. Quick Return On Investment (5-10 years)

\section{Applications}

1) Rivers

2) Cooling water outlets from power stations

3) Industrial process water (for example Project or steel mills)

4) Water treatment inlets (Municipal and Industry)

5) Water treatment outfalls (Municipal and Industry)

6) Replacement of waterwheels and other types of generators 


\section{III.CONCLUSION}

The Micro hydropower based on Archimedean turbine is an eco-friendly, fish friendly \& there is no requirement of deforestation as well as people displacement and other harassments. In these types of plant there are no requirements of big dam, high Discharge, high Head \& penstock etc. The efficiency of plant does not vary with load, but Power output \& Speed of this plant vary with discharge at same Head condition. Hence this type Micro hydropower based on Archimedean turbine plant is most suitable hydro power plant in the present as well as future.

\section{REFERENCES}

[1] Aigner , D. (2008). Uberfalle - Asserbauliche Mittelungen - Aktuelle Forschungen im Wasservau 1993-2008. Institut fur Wasserbau und Technische Hydromechanik der TU Dresden. Selbstverlag der Technischen universitat Dresden, Dresden, 36.

[2] Bard, N. (2007). River Dart Hydro Performance Assessment By Nick Bard Hydro Services For Mannpower Consulting Ltd. Nick Bard Hydro Services, 44(0). Retrieved from http://www.mannpower-hydro.co.uk/research.php

[3] Brada, K. (1996). Schneckentrogpumpe als Mikroturbine, in Wasserkraftanlagen - Klein- und kleinstkraftwerke. expert-Verlag, Malsheim, 1st edition.

[4] Brada, K. (1999). Wasserkraftschnecke ermöglicht Stromerzeugung über Kleinkraftwerke [Hydraulic screw generates electricity from micro hydropower stations]. Maschinenmarkt Würzburg, (14), 52-56.

[5] Hawle, W., Lashofer, A., \& Pelikan, B. (2012a). Lab Testing of the Archimedean Screw. hidroenergia.

[6] Hawle, W., Lashofer, A., \& Pelikan, B. (2012b). State of technology and design guidelines for the Archimedes screw turbine. University of Natural Resources and Life Sciences Vienna (BOKU), 1-8.

[7] Kibel, P. (2008). Archimedes Screw Turbine Fisheries Assessment. Phase II: Eels and Kelts. Report. Fishtek Consulting Ltd. (UK).

[8] Kibel, P., Pike, R., Coe, T. (2009). The Archimedes Screw Turbine: Assessment of Three Leading Edge Profiles. Report. Fishtek Consulting Ltd. (UK).

\section{BIOGRAPHIES}

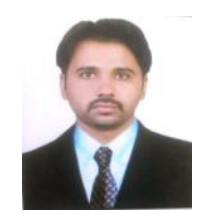

Prof.Sagar P. Thombare, ME (Power Electronic and Drives), Associate Member of Institute of Engineer's, Published Four International Papers in Reputed Journals, Head of Department, Electrical Engineering, Matoshri Aasarabai Polytechnic, Nashik.

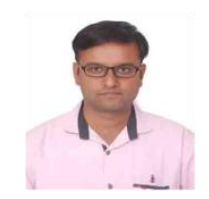

Prof.Vikrant D. Nichit, ME (Design), Associate Member of Institute of Engineer's, Published Four International Papers in Reputed Journals, Head of Department, Mechanical Engineering, Matoshri Aasarabai Polytechnic, Nashik.

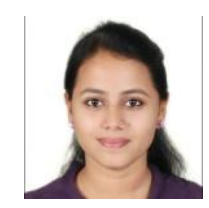

Prof. Priyanka K. Hire, ME (Power System- Appear), Associate Member of Institute of Engineer's, Published Four International Papers in Reputed Journals, Lecturer, Electrical Department, Matoshri Aasarabai Polytechnic, Nashik. 